\title{
Valanginian occurrence of Pelomedusoides turtles in northern South America: Revision of this hypothesis based on a new fossil remain
}

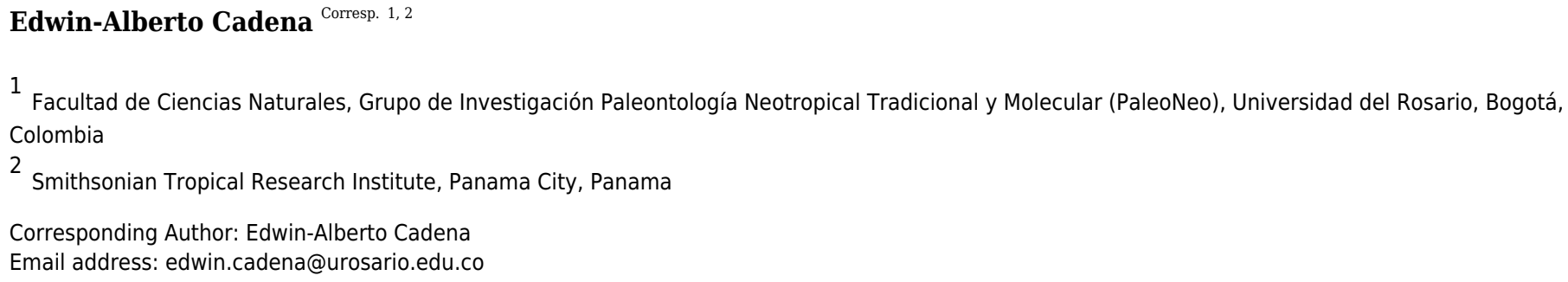

Pelomedusoides constitutes the most diverse group of Mesozoic and Cenozoic side-necked turtles. However, when it originated is still being poorly known and controversial. Fossil remains from the Early Cretaceous (Valanginian) Rosa Blanca Formation of Colombia were described almost a decade ago as potentially belonging to Podocnemidoidea (a large subclade inside Pelomedusoides) and representing one of the earliest records of this group of turtles. Here, I revise this hypothesis based on a new fragmentary specimen from the Rosa Blanca Formation, represented by a right portion of the shell bridge, including the mesoplastron and most of peripherals 5 to 7 . The equidimensional shape of the mesoplatron allows me to support its attribution as belonging to Pelomedusoides, a group to which the previously podocnemidoid material is also attributed here. Although the Valanginian pelomesudoid material from Colombia is still too fragmentary as to be considered the earliest indisputable record of the Pelomedusoides clade, their occurrence is at least in agreement with current molecular phylogenetic hypotheses that suggest they split from Chelidae during the Jurassic and should occur in the Late Jurassic and Early Cretaceous fossil record. 


\section{Valanginian occurrence of Pelomedusoides turtles in}

2 northern South America: Revision of this hypothesis

3 based on a new fossil remain.

4

Edwin-Alberto Cadena ${ }^{1,2}$

${ }^{1}$ Facultad de Ciencias Naturales, Grupo de Investigación Paleontología Neotropical Tradicional

8 y Molecular (PaleoNeo), Universidad del Rosario, Bogotá, Colombia

9 2Smithsonian Tropical Research Institute, Panama City, Panama

10

11

12

Corresponding Author:

Edwin-Alberto Cadena ${ }^{1}$

Cra 26 63b-48, Bogotá, 111221, Colombia

Email address: edwin.cadena@urosario.edu.co

\section{Abstract}

Pelomedusoides constitutes the most diverse group of Mesozoic and Cenozoic side-necked turtles. However, when it originated is still being poorly known and controversial. Fossil remains from the Early Cretaceous (Valanginian) Rosa Blanca Formation of Colombia were described almost a decade ago as potentially belonging to Podocnemidoidea (a large subclade inside Pelomedusoides) and representing one of the earliest records of this group of turtles. Here, I revise this hypothesis based on a new fragmentary specimen from the Rosa Blanca Formation, represented by a right portion of the shell bridge, including the mesoplastron and most of peripherals 5 to 7 . The equidimensional shape of the mesoplatron allows me to support its attribution as belonging to Pelomedusoides, a group to which the previously podocnemidoid material is also attributed here. Although the Valanginian pelomesudoid material from Colombia is still too fragmentary as to be considered the earliest indisputable record of the Pelomedusoides clade, their occurrence is at least in agreement with current molecular phylogenetic hypotheses that suggest they split from Chelidae during the Jurassic and should occur in the Late Jurassic and Early Cretaceous fossil record.

\section{Introduction}

One of the most diverse clades of Mesozoic and Cenozoic turtles is Pelomedusoides, with fossils worldwide distributed and extant representatives restricted to southern hemisphere (Ferreira et al. 2018; Gaffney et al. 2011; Gaffney et al. 2006; Hermanson et al. 2020; Vlachos et al. 2018). Recent molecular phylogenetic hypotheses suggest that they split from Chelidae during the Late Jurassic at 161.7 Ma (149.3-168.9 Ma) (Pereira et al. 2017), and total-evidence tip-dating (TE 
40 TD) suggest even older date for this splitting during the Early Jurassic at 172.6 Ma (Holley et al. 2019). However, at present, the earliest indisputable fossil record of Pelomedusoides is the bothremydid Atolchelys lepida (Romano et al. 2014), from the upper Barremian of Brazil; meaning approximately $36 \mathrm{Ma}$ of ghost-lineage.

Almost a decade ago, I described some fragmentary material from the Early Cretaceous (Valanginian) Rosa Blanca Formation of Colombia, which I attributed as potentially belonging to Podocnemidoidea (one of the subclades inside Pelomedusoides) (Cadena 2011). This occurrence has been questioned and considered dubious by Romano et al (2014), arguing that the presence of an inguinal buttress that medially extends onto the ventral surface of costal 5 is highly variable within Pelomedusoides, even within all of Testudines. Here, I present new material from a locality nearby to the one from where the material described in 2011 came from; from the same segment of the Rosa Blanca Formation (Fig. 1). This new fossil material allows me to revise the hypothesis proposed back in 2011, and present new evidence and comparisons that support the occurrence of Pelomedusoides during the Valanginian in northern South America.

\section{Material \& Methods}

Fossil material. I found the fragmentary material described here in 2016. Recently I added it to the emerging Paleontological Collection of the Facultad de Ciencias Naturales from Universidad del Rosario, in Bogotá, Colombia. Its collection identification number is UR-CP-0025. I obtained permit from the Ethics committee of the Universidad del Rosario to execute this study via the DVO005 672-Cv1066 communication. Local landowner Roberto Serrano verbally authorized the paleontological exploration of the zone and collection of the specimen.

Institutional abbreviations. CRI, Chelonian Research Institute, Oviedo, Florida, USA; IPN, Museo Geológico Nacional José Royo y Goméz, Bogotá, Colombia; MNHN, Muséum National d'Histoire Naturelle, Paris, France; UR-CP, paleontological collection, Facultad de Ciencias Naturales, Universidad del Rosario, Bogotá, Colombia; USNM, herpetological collection, Smithsonian Natural History Museum, Maryland, USA.

Carapace length estimation. In order to establish an estimation of the total length of the carapace to which the fossil fragment belongs, I measured fifteen specimens of extant podocnemidids that I have examined in recent years, as well as the extinct taxa Francemys gadoufaouaensis from Pérez-García (2019) and Atolchelys lepida from Romano et al (2014) (Data. S1). Using the software Image J2 (Rueden et al. 2017), I set the scale to the one provided in the photos or figures of the specimens and measured the maximum length of both mesoplastra, peripherals 6,7 , and the total length of the carapace (according to their individual preservation). I 
81

82

83

84

85

86

87

88

89

90

91

92

93

94

95

96

97

98

99

100

101

102

103

104

105

106

107

108

109

110

111

112

113

114

115

116

117

118

established the simple linear regression and its equation using Microsoft-Excel (Data. S1), and used it to estimate the maximum length of the carapace of UR-CP-0025.

Comparisons. For comparisons with other pan-pleurodires including several Pelomedusoides, I created a comparative figure redrawing only the right bridge region from figures or photographs of previous literature or from direct examination of specimens as follow: Platychelys oberndorferi, Notoemys laticentralis, and Notoemys zapatocaensis from Cadena \& Joyce (2015); Notoemys oxfordiensis from de la Fuente \& Iturralde-Vinent (2001); Francemys gadoufaouaensis from Pérez-García (2019); Bonapartemys bajobarrealis from Lapparent de Broin \& de la Fuente (2001); Mendozachelys wichmanni from de la Fuente et al (2017); Prochelidella cerrobarcinae from de la Fuente et al (2011); Euraxemys essweini and Cearachelys placidoi from Gaffney et al (2006); Araripemys barretoi from Meylan (1996); Dortoka vasconica from Lapparent de Broin \& Murelaga (1996); Pelomedusa subrufa CRI5200, Podocnemis expansa USNM-29476 and Chelus fimbriata MNHN-2581A from personal reference photo gallery; and UR-CP-0025 from this study.

\section{Results}

\section{Systematic Paleontology}

PLEURODIRA Cope, 1864

PELOMEDUSOIDES Cope, 1868

Incertae Sedis

Fig. 2

Referred material.-UR-CP-0025, a portion of the right shell bridge including the mesoplastron, peripheral 6, portions of peripherals 5 and 7, as well as the lateral most portions of right hyoplastron and hypoplastron. From Cadena (2011): IPN 16 EAC-14012003-1A, left partial costal 5; IPN 16 EAC-14012003-1B, posterior peripheral bone.

Locality and Age.-I collected UR-CP-0025 from a locality nearby the Laguna del Sapo $\left(6^{\circ} 50^{\prime} 34^{\prime \prime} \mathrm{N},-73^{\circ} 14^{\prime} 17.3^{\prime \prime} \mathrm{W}\right)$, approximately $1.5 \mathrm{~km}$ southwest of the Pico de la Vieja road locality where I found the material reported in Cadena (2011) (Fig. 1A-B). The Laguna del Sapo locality is northeast of Zapatoca, Santander Department, Colombia; and it is part of the recently defined Carrizal Member of the shallow marine Rosa Blanca Formation (Etayo-Serna \& Guzmán-Ospitia 2019), correlated to the base of the late Valanginian ( 135 Ma) based on the occurrence of the ammonite Saynoceras verrucosum, according to the biochronostratigraphic framework of Ogg et al (2016). I found UR-CP-0025 at the base of a calcareous yellow siltstone layer (Fig. 1C).

Remarks.-UR-CP-0025 is attributed as belonging to Pelomedusoides based on having an equidimensional mesoplastron (Fig. 3). IPN 16 EAC-14012003-1A (Cadena 2011, fig. 1) is also 
119 reassigned as potentially belonging to Pelomedusoides based on the massive inguinal buttress 120 scar extending medially onto it, as well as ventrally projected (Character 150, Gaffney et al., 121 2006). Romano et al (2014) ignored that the character used is dealing with the degree of

122 extension of the inguinal buttress as clearly pointed out in Cadena (2011, fig. 1) with examples in different Testudines. IPN 16 EAC-14012003-1B is similar in size to the peripherals of UR-CP0025 described herein, much larger than the peripherals of Notoemys zapatocaensis (Cadena et al., 2013), making it also potentially belonging to Pelomesudoides".

126

127

128

129

130

131

132

133

134

135

136

137

138

139

140

141

142

143

144

145

146

147

148

149

150

151

152

153

154

155

156

157

158

Description. UR-CP-0025 constitutes a portion of the right shell bridge, preserving the mesoplastron, the most posterolateral corner of the right hyoplastron, the most anterolateral portion of the right hypoplastron, peripheral 6 , and portions of peripherals 5 and 7 . In ventral view (Fig. 2A-B), the mesoplastron exhibits an almost equidimensional circular-shape, and it is in lateral and posterolateral contact with peripherals 5 and 6 respectively. Medially and posteromedially is in contact with the right hyoplastron and right hypoplastron respectively. The most lateral portion of peripherals 5 to 7 is missing (natural breaking). Also in this view, there is evidence of some of the sulci, particularly between marginals and of these with the abdominal scute. There is not indication that the pectoroabdominal sulcus reached the anterolateral corner of mesoplastron. In dorsal and lateral views (Fig. 2C-F), the peripheral 6 is the most complete of the three preserved, showing a rectangular shape with its most medial margin (contact with costals) missing. The sulci between marginals are poorly preserved, however there is enough evidence that they were restricted to the peripherals, without reaching the costoperipheral sutural margin. The sutural contact between peripherals shows a medial indentation (Fig. 2E-F), however this seems to be due to that the bone is naturally cut and cancellous tissue exposed. In anterior view (Fig. 2G-H), the peripheral 5 and mesoplastron contact is well defined, and the bridge angle formed between the peripherals and the plastron indicates that the shell was probably low to moderate dome-shaped. Also in this view is evident the considerable thickness of these bones. A close-up of the margin of peripheral 5 (Fig. 2I-J) shows a very thin external bone cortex and abundance of large pores at the cancellous bone. A large $(88.17 \mathrm{~cm}$, carapace length) of the extant Podocnemis expansa USNM-29476 is shown in Fig. 2K for comparison and anatomical location of UR-CP-0025 in a turtle shell.

\section{Discussion}

Mesoplastra of Pan-Pleurodira. The mesoplastra bones have exhibited important modifications along turtle evolution. In basal Pan-Testudines as for example Odontochelys semitestacea they were two separate bony plates meeting medially (Li et al. 2008). In basal Testudines as for example Kayentachelys aprix there was a reduction in the number of mesoplastra, being only one pair extended medially reaching the central fontanelle (Joyce 2007, fig. 11). Another transformation of mesoplastra occurred in the both major groups of turtles, with their complete lost in Cryptodires and being one pair but they do not contact one another medially in PanPleurodira (Cadena \& Joyce 2015; Joyce 2007). Inside Pan-Pleurodira the mesoplastra have 
159

160

161

162

163

164

165

166

167

168

169

170

171

172

173

174

175

176

177

178

179

180

181

182

183

184

185

186

187

188

189

190

191

192

193

194

195

196

197

exhibited additional transformations from the primitive condition exhibited by Platychelyidae and Cretaceous-Paleocene members of Pan-Chelidae (Fig. 3A-C, G-I) of being almost triangular in shape, much wider than long to the condition exhibited by almost all Pelomedusoides of having almost equidimensional mesoplastra (Fig. 3E-F, J-L, P). An equidimensional mesoplastron was considered by Gaffney et al (2006) as characteristic of a Nanorder that they defined as Eupleurodira (Cheloides = Pan-Chelidae plus Pelomedusoides). As I show in Fig. 3, the condition in pan-chelids who have mesoplastra is similar to the one exhibited by platychelids, which allow me to suggest that instead this is a characteristic of Pelomedusoides, shared by URCP-0025 described herein (Fig. 3E). Another transformation of mesoplastra inside PanPleurodira is their complete lost in some Dortokidae, some Araripemydidae, crown-Chelidae, and Pelusios spp. (Gaffney et al. 2006) (Fig. 3M-O).

Carapace size estimation of UR-CP-0025. Using the simple linear regression equation $(\mathrm{y}=$ $6.5362 \mathrm{x}+5.5002$, $\mathrm{x}$ corresponding to maximum mesoplastron length, and y maximum carapace length) obtained from specimens of extant podocnemidids and some fossil pelomedusoids (Data. S1). I estimated that the length of the carapace of UR-CP-0025 was of $\sim 40.59 \mathrm{~cm}$, indicating a much larger size in contrast to the exhibited by Jurassic and Early Cretaceous platychelids, which fluctuated between 20 to $27 \mathrm{~cm}$ (Cadena et al. 2013, table 8.1). This suggests that the increase in shell size was a characteristic exhibited by early representatives of Pelomedusoides; a trend that continued during the Late Cretaceous (Hermanson et al. 2016) and the Cenozoic, with the giant pelomedusoids from the Paleocene of Colombia (Cadena et al. 2012a; Cadena et al. 2012b), and the Miocene Stupendemys geographicus from northern South America (Cadena et al. 2020).

\section{Implications of UR-CP-0025 for Pelomedusoides history understanding. With the} description of UR-CP-0025 and its attribution as belonging to Pelomedusoides (see above), I show that they inhabited northern South America during the Early Cretaceous. A hypothesis that is in agreement with recent molecular phylogenetic hypotheses that suggest they split from Chelidae during the Jurassic (Holley et al. 2019; Pereira et al. 2017), therefore their fossil record should be expected to occur in Late Jurassic and Early Cretaceous sequences (Fig. 3Q). However, it is important to point out that UR-CP-0025 and the material previously described also from Rosa Blanca Formation (Cadena 2011) are still too fragmentary to be recognized as the earliest indisputable record of the group, which it is not intention of this study. With this study, I once again showed that the Rosa Blanca Formation is still being a very productive and promising rock sequence in northern South America for future paleontological studies and the understanding of the Early Cretaceous faunas, including the evolution of Pelomedusoides turtles.

\section{Conclusions}


198

199

200

201

202

203

204

205

206

207

208

209

210

211

212

213

214

215

216

217

218

219

220

221

222

223

224

225

226

227

228

229

230

231

232

233

234

235

236

237

238

239

240

241

242

243

With this study, I once again showed that the Rosa Blanca Formation is still being a very productive and promising rock sequence in northern South America for future paleontological studies and the understanding of the Early Cretaceous faunas, including the evolution of Pelomedusoides turtles. Despite the taxonomic uncertainty that fragmentary material as UR-CP0025 has, it exhibits the characteristic equidimensional mesoplastron of Pelomedusoides turtles, supporting the occurrence of this group of turtles in northern South America during the Early Cretaceous.

\section{Acknowledgements}

Thanks to A. Alfonso-Rojas for help in cataloging and photographing the specimen. Thanks to P. Pritchard (R.I.P) (Chelonian Research Institute), F. Lapparent de Broin (Muséum National d'Histoire Naturelle), O. Castaño (Instituto de Ciencias Naturales) and staff at the Smithsonian Natural History Museum for access to the collections. Thanks to R. Serrano for access to the zone where the specimen was collected. Thanks to the three reviewers; M, de la Fuente, A. Pérez García, and N, Benevenuto for the insightful comments, as well as PeerJ editor M. Young.

\section{References}

Cadena EA. 2011. Potential earliest record of podocnemidoid turtles, from the Early Cretaceous (Valanginian) of Colombia. Journal of Paleontology 85:877-881.

Cadena EA, Bloch JI, and Jaramillo C. 2012a. New bothremydid turtle (Testudines, Pleurodira) from the Paleocene of northeastern Colombia. Journal of Paleontology 86:689-699.

Cadena EA, Jaramillo CA, and Bloch JI. 2013. New material of the Platychelyid turtle Notoemys zapatocaensis from the Early Cretaceous of Colombia; implications for understanding Pleurodira evolution. In: Brinkman DB, Holroyd PA, and Gardner JD, eds. Morphology and Evolution of Turtles. Dordrecht: Springer, 105-120.

Cadena EA, and Joyce WG. 2015. A review of the fossil record of turtles of the clades Platychelyidae and Dortokidae. Bulletin of the Peabody Museum of Natural History 56:3-20.

Cadena EA, Ksepka DT, Jaramillo CA, and Bloch JI. 2012b. New pelomedusoid turtles from the late Palaeocene Cerrejón Formation of Colombia and their implications for phylogeny and body size evolution. Journal of Systematic Palaeontology 10:313-331.

Cadena EA, Scheyer TM, Carrillo-Briceno JD, Sanchez R, Aguilera-Socorro OA, Vanegas A, Pardo M, Hansen DM, and Sanchez-Villagra MR. 2020. The anatomy, paleobiology, and evolutionary relationships of the largest extinct side-necked turtle. Science Advances 6:eaay4593.

de la Fuente MS, and Iturralde-Vinent M. 2001. A new pleurodiran turtle from the Jagua Formation (Oxfordian) of Western Cuba. Journal of Paleontology 75:860-869.

de la Fuente MS, Maniel I, Jannello JM, Sterli J, Gonzalez-Riga B, and Novas F. 2017. A new large panchelid turtle (Pleurodira) from the Loncoche Formation (upper Campanian-lower Maastrichtian) of the Mendoza Province (Argentina): Morphological, osteohistological studies, and a preliminary phylogenetic analysis. Cretaceous Research 69:147-168.

de la Fuente MS, Umazano AM, Sterli J, and Carballido JL. 2011. New chelid turtles of the lower section of the Cerro Barcino formation (Aptian-Albian?), Patagonia, Argentina. Cretaceous Research 32:527-537.

Etayo-Serna F, Guzmán-Ospitia, G. 2019. Formación Rosa Blanca: subdivisión de la Formación y propuesta de Neoestratotipo. Sección laguna El Sapo, vereda El Carrizal, municipio de Zapatoca, 
244

245

246

247

248

249

250

251

252

253

254

255

256

257

258

259

260

261

262

263

264

265

266

267

268

269

270

271

272

273

274

275

276

277

278

279

280

281

282

283

284

285

286

287

288

289

290

291

292

293

departamento de Santander. In: Etayo-Serna F. ed. Estudios geológicos y paleontológicos sobre el Cretácico en la región del embalse del río Sogamoso, Valle Medio del Magdalena. Compilación de los Estudios Geológicos Oficiales en Colombia XXIII. Bogotá: Servicio Geológico Colombiano, 3-54.

Ferreira GS, Bronzati M, Langer MC, and Sterli J. 2018. Phylogeny, biogeography and diversification patterns of side-necked turtles (Testudines: Pleurodira). Royal Society Open Science 5:1-17.

Gaffney ES, Meylan PA, Wood RC, Simons E, and de Almeida Campos D. 2011. Evolution of the sidenecked turtles: the family Podocnemididae. Bulletin American Museum of Natural History 350:1237.

Gaffney ES, Tong H, and Meylan PA. 2006. Evolution of the side-necked turtles: the families Bothremydidae, Euraxemydidae, and Araripemydidae. American Museum Novitates 300:1-700.

Hermanson G, Ferreira GS, and Langer MC. 2016. The largest Cretaceous podocnemidoid turtle (Pleurodira) revealed by an isolated plate from the Bauru Basin, south-central Brazil. Historical Biology: DOI:10.1080/08912963.2016.1248434.

Hermanson G, Iori FV, Evers SW, Langer MC, and Ferreira GS. 2020. A small podocnemidoid (Pleurorida, Pelomedusoides) from the Late Cretaceous of Brail, and the innervation and carotid circulation of side-necked turtles. Papers in Palaeontology:1-19. DOI: 10.1002/spp2.1300.

Holley JA, Sterli J, and Basso NG. 2019. Dating the origin and diversification of Pan-Chelidae (Testudines, Pleurodira) under multiple molecular clock approaches. Contributions to Zoology:129.

Joyce WG. 2007. Phylogenetic relationships of Mesozoic turtles. Bulletin of the Peabody Museum of Natural History 48:3-102.

Lapparent de Broin F, and de la Fuente MS. 2001. Oldest world Chelidae (Chelonii, Pleurodira), from the Cretaceous of Patagonia, Argentina. Comptes Rendus de l'Académie des Science de Paris 333:463-470.

Lapparent de Broin F, and Murelaga X. 1996. Une nouvelle faune de chloniens dans le Crétacé supérieur européen. Comptes Rendus de l'Académie des Sciences de Paris 323:729-735.

Li C, Wu XC, Rieppel O, Wang LT, and Zhao LJ. 2008. An ancestral turtle from the Late Triassic of southwestern China. Nature 456:497-501.

López-Conde OA, Sterli J, Alvarado-Ortega J, and Chavarría-Arellano ML. 2017. New platychelid turtle (Pan-Pleurodira) from the Late Jurassic (Kimmeridgian) of Oxaca, Mexico. Papers in Paleontology DOI: 10.1002/spp2.1069.

Meylan PA. 1996. Skeletal morphology and relationships of the Early Cretaceous side-necked turtle, Araripemys barretoi (Testudines: Pelomedusoides: Araripemydidae), from the Santana Formation of Brazil. Journal of Vertebrate Paleontology 16:20-33.

Ogg JG, Ogg G, and Gradstein FM. 2016. A concise Geologic Time Scale 2016: Elsevier.

Pereira AG, Sterli J, Moreira FRR, and Schrago CG. 2017. Multilocus phylogeny and statistical biogeography clarify the evolutionary history of major lineages of turtles. Molecular Phylogenetics and Evolution 113:59-66.

Pérez-García A. 2019. The African Aptian Francemys gadoufaouaensis gen. et sp. nov.: New data on the early diversification of Pelomedusoides (Testudines, Pleurodira) in northern Gondwana. Cretaceous Research 102:112-126.

Romano PS, Gallo V, Ramos RR, and Antonioli L. 2014. Atolchelys lepida, a new side-necked turtle from the Early Cretaceous of Brazil and the age of crown Pleurodira. Biology Letters 10: 20140290.

Rueden CT, Schindelin J, and Hiner MC. 2017. ImageJ2: ImageJ for the next generation of scientific image data. BMC Bioinformatics 18.

Vlachos E, Randolfe E, and Sterli J. 2018. Changes in the diversity of turtles (Testudinata) in South America from the Late Triassic to Present. Ameghiniana 55:619-643.

Peer] reviewing PDF | (2020:06:49823:1:1:NEW 15 Jul 2020) 


\section{Figure 1}

Geographic location of UR-CP-0025 Pelomedusoides fossil turtle fragment

Figure 1. The geographic location of UR-CP-0025 Pelomedusoides fossil turtle fragment. (A) Map of South America, Colombia, and Santander Department, including the study area. (B) Northeast region of Zapatoca showing the three localities from which fossil turtles have been collected: El Caucho Farm, the type locality for Notoemys zapatocaensis (Cadena et al. 2013); Pico de la Vieja road, from where IPN 16 EAC-14012003-1A and IPN 16 EAC-14012003-1B (Cadena 2011) referred here to Pelomedusoides came from; and Laguna del Sapo locality from where UR-CP-0025 Pelomedusoides described here came from. (C) Laguna del Sapo locality outcrop showing the discovery of UR-CP-0025 at the base of a calcareous yellow siltstone layer. 


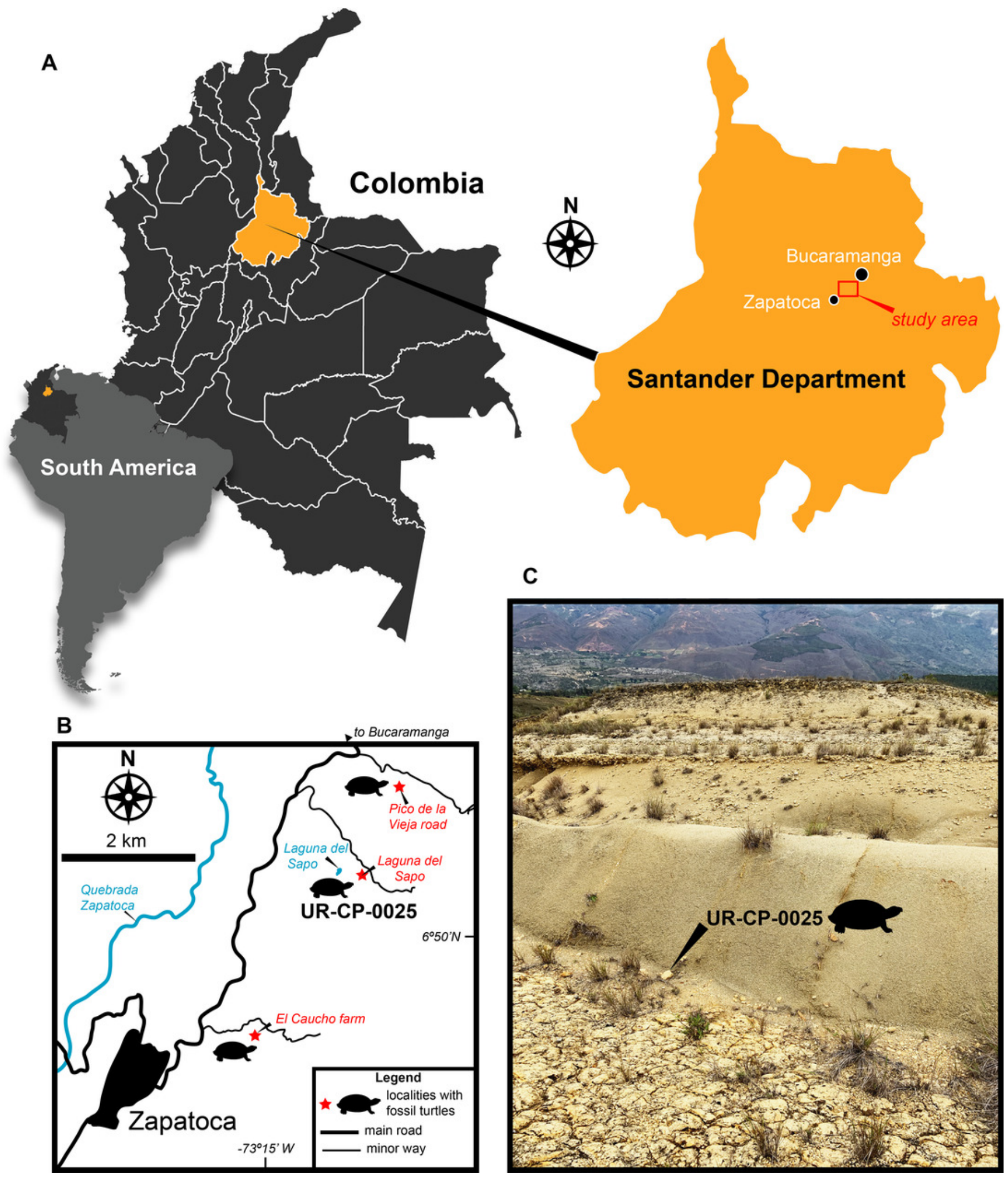




\section{Figure 2}

UR-CP-0025 Pelomedusoides shell bridge fragment from the Valaginian of Colombia.

Figure 2. UR-CP-0025 Pelomedusoides shell bridge fragment from the Valaginian of

Colombia. (A-B) ventral view. (C-D) dorsal view. (E-F) lateral view. (G-H) anterior view. (I-J) close-up of the margin of peripheral 5, showing the external cortex and cancellous bone. (K) A complete shell in ventral view of Podocnemis expansa USNM-29476 specimen, grey region indicates the anatomical corresponding part preserved in UR-CP-0025. Abbreviations: Ab, abdominal scute; An, anal scute; ent, entoplastron; EC, external cortex; epi, epiplastron; Ex, extragular scute; Fe, femoral scute; Gu, gular scute; Hu, humeral scute; hyo, hyoplastron; hyp, hypoplastron; M, marginal scute; mes, mesoplastron; pe, peripheral; py, pygal; xip, xiphiplastron. $10 \mathrm{~cm}$ scale bar applies only for $\mathrm{K}$. Red lines indicate sulci, and dotted lines possible shape and location. Photo credits (A, C, E, D): A. Alfonso-Rojas. 
A

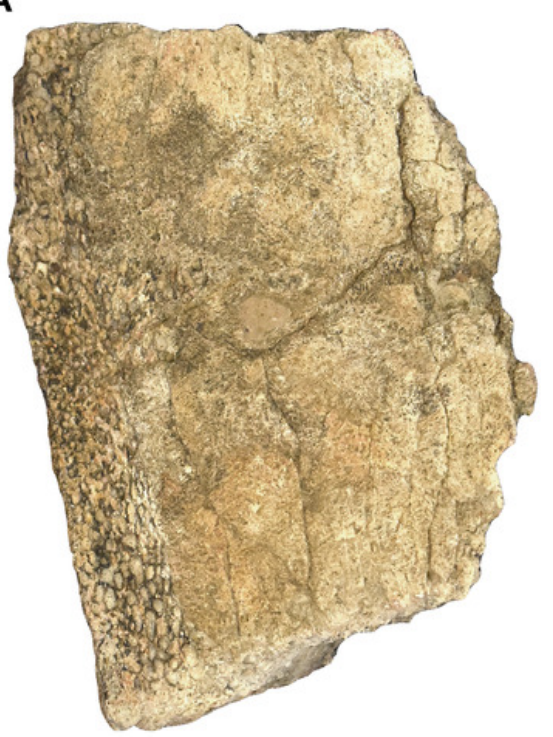

C

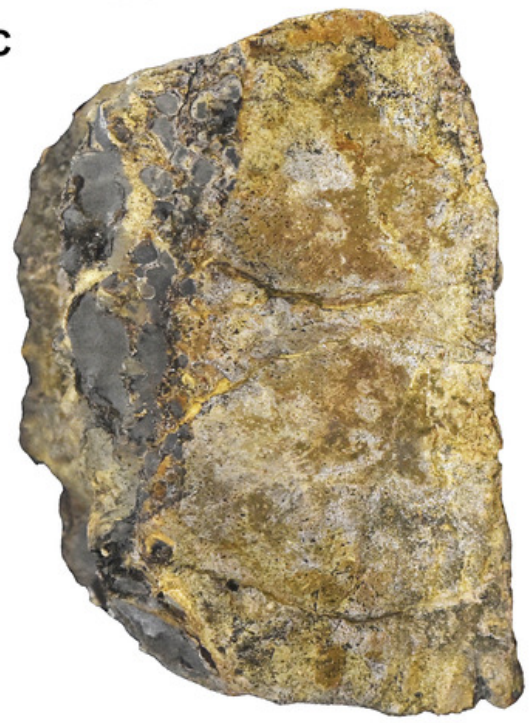

B

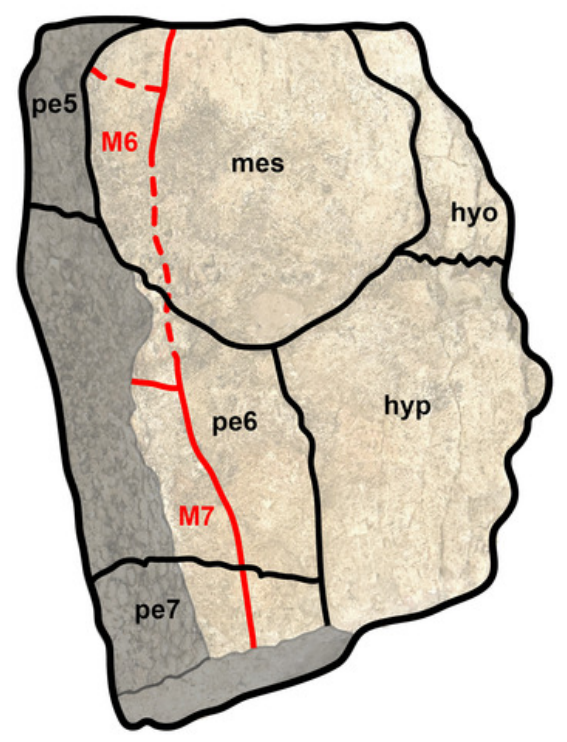

D

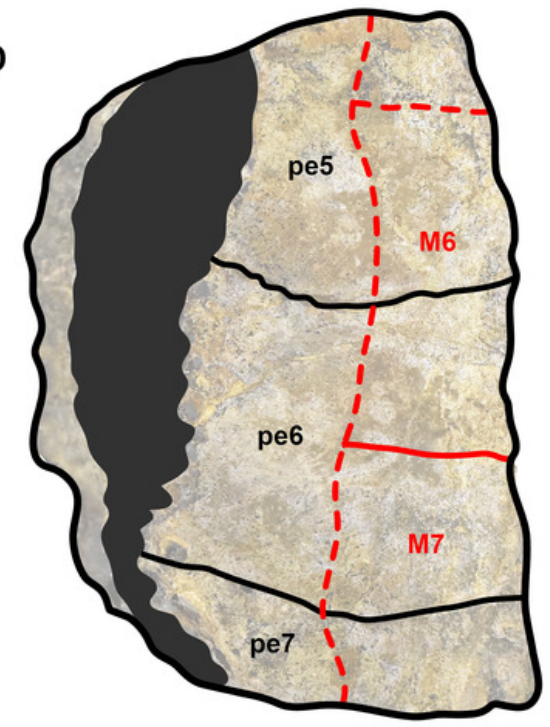

E

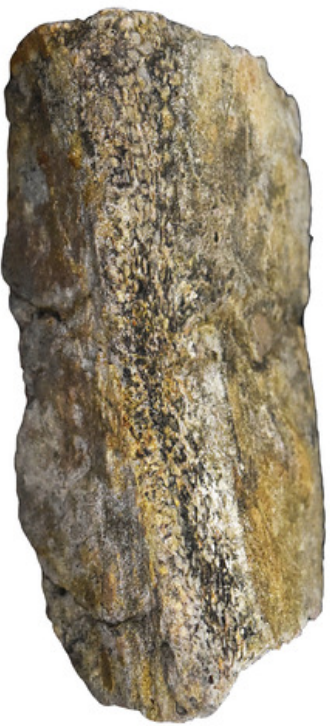

F

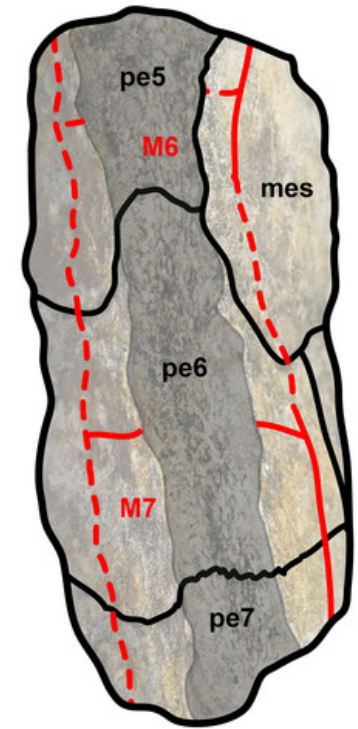

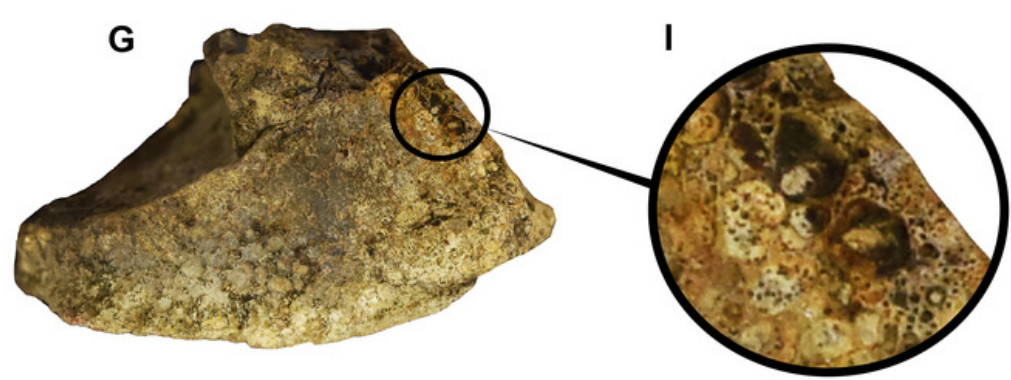
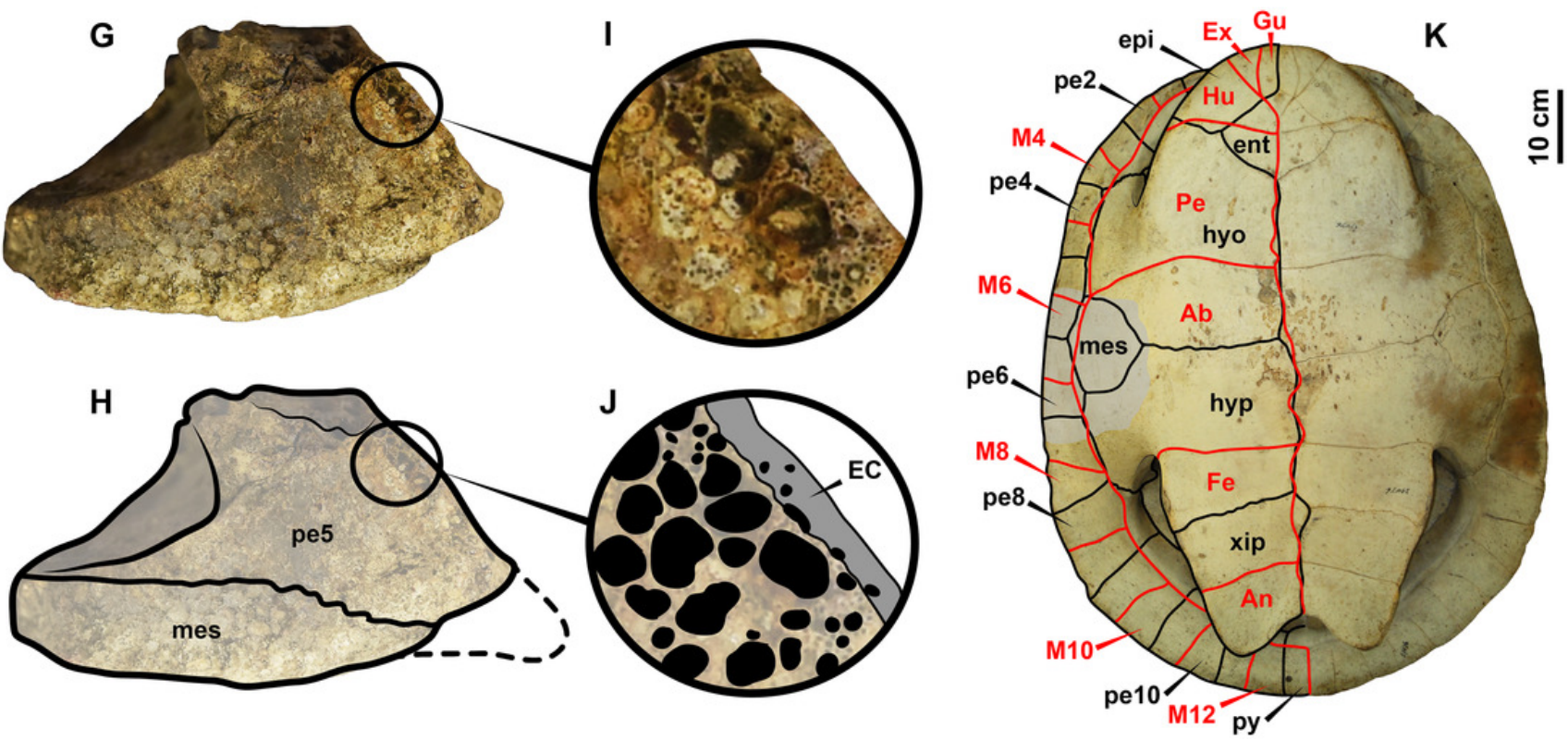

PeerJ reviewing PDF | (2020:06:49823:1:1:NEW 15 Jul 2020) 


\section{Figure 3}

Comparisons of the right shell bridge for several pan-pleurodires and their simplified phylogeny

Figure 3. Comparisons of the right shell bridge for several pan-pleurodires and their simplified phylogeny. (A) Platychelys oberndorferi. (B) Notoemys oxfordiensis. (C) Notoemys laticentralis. (D) Notoemys zapatocaensis. (E) UR-CP-0025 Pelomedusoides. (F) Francemys gadoufaouaensis. (G) Bonapartemys bajobarrealis. (H) Mendozachelys wichmanni. (I) Prochelidella cerrobarcinae. (J) Pelomedusa subrufa CRI-5200. (K) Euraxemys essweini. (L) Cearachelys placidoi. (M) Araripemys barretoi. (N) Dortoka vasconica. (0) Chelus fimbriata MNHN-2581A (P) Podocnemis expansa USNM-29476. (Q) Simplified phylogeny of PanPleurodira based on López-Conde et al (2016) and Hermanson et al (2020), with the potential position of UR-CP-0025 and Francemys gadoufaouaensis (Pérez-García 2019); Atolchelys lepida (Romano et al. 2014) included inside Bothremydidae. Abbreviations: Ma, million years; mes, mesoplastron; hyo, hyoplastron; hyp, hypoplastron; pe, peripheral. See methods for full references of the taxa illustrated here. Right mesoplastron highlighted in orange-yellow. 

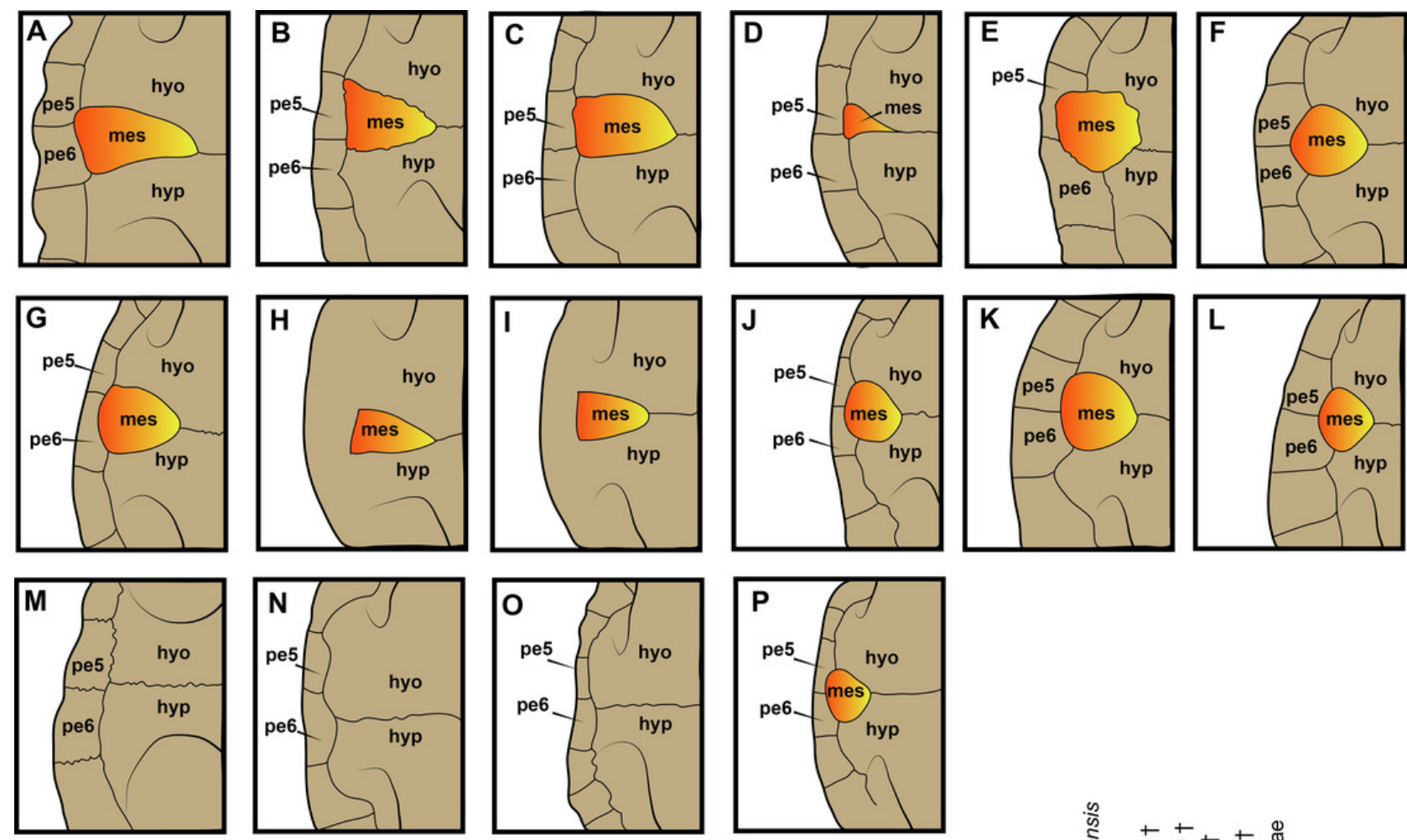

Q

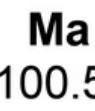

145.0
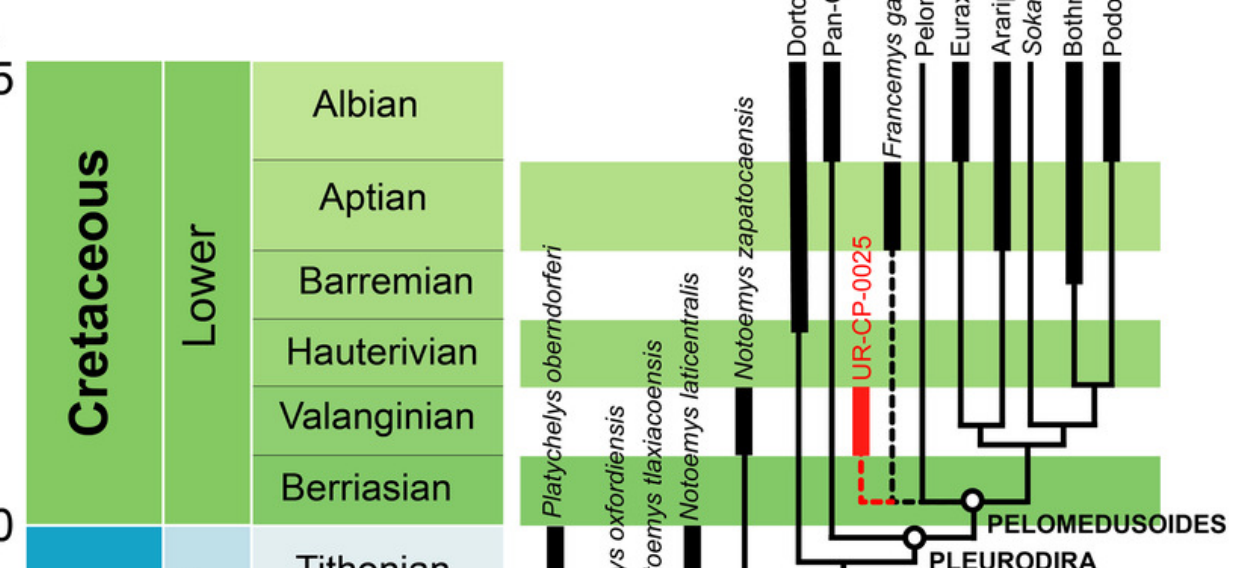

163.5
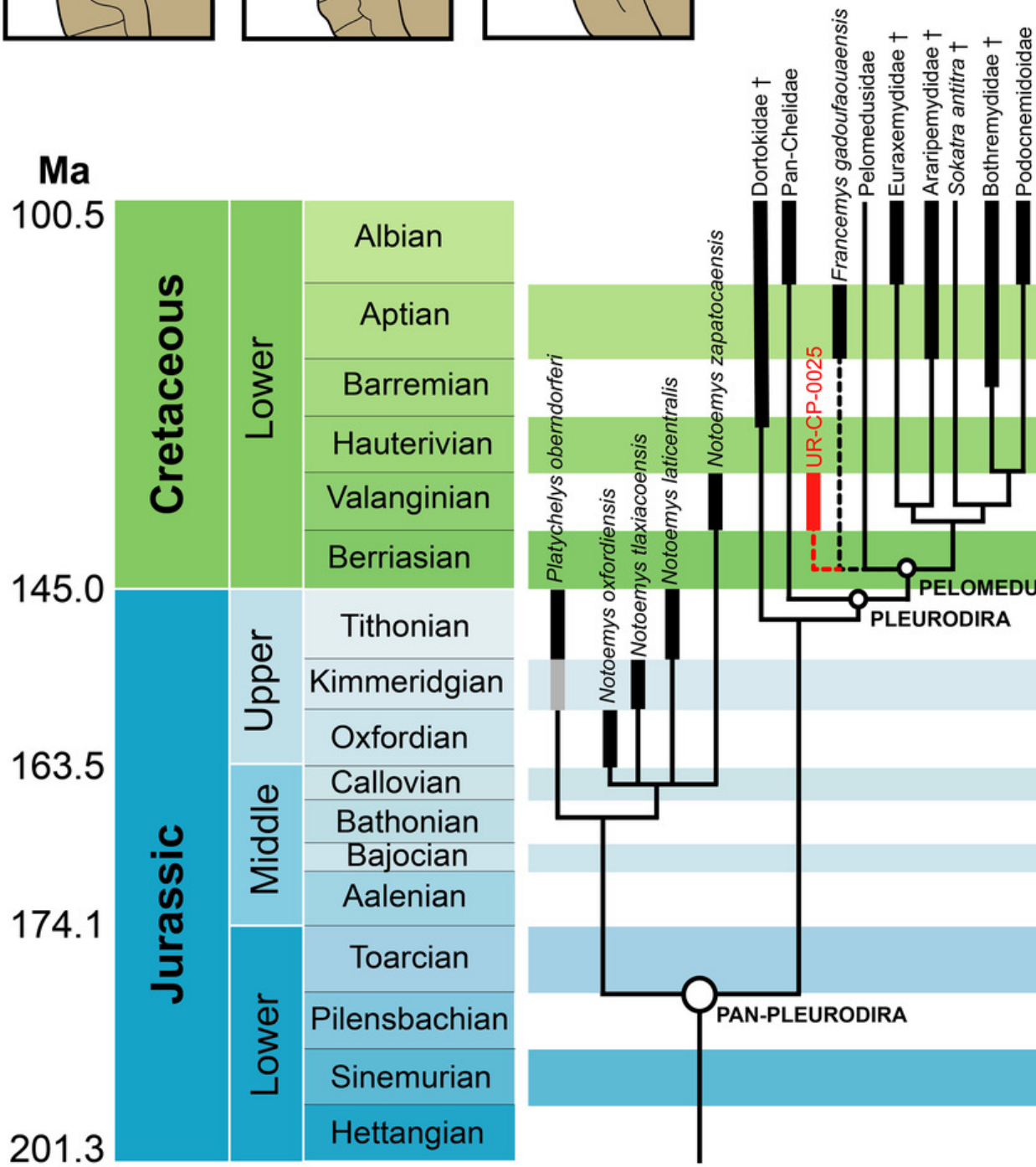